\title{
Two worlds apart? Export demand shocks and domestic sales
}

\author{
Aksel Erbahar ${ }^{1,2}$ (iD) \\ Published online: 23 September 2019 \\ (c) The Author(s) 2019
}

\begin{abstract}
This paper, using a rich dataset on Turkish firms for the 2005-2014 period, analyzes the relationship between firm-product sales in different markets to identify the channels that link exports and domestic sales. First, I use an instrumental variables strategy and establish that an exogenous $10 \%$ rise in exports increases a firm's domestic sales by $2.6 \%$ on average. Second, I do an analogous exercise at the firm-product level, and find coefficients that are almost twice as large, hinting to the importance of product-specific scale effects. Moreover, I propose a novel approach to isolate the production versus non-production factors that influence firm dynamics by focusing on non-produced (or carry-along trade, CAT) exports. I find that CAT exports also affect domestic sales positively, suggesting that spillovers at the firm level such as the easing of liquidity constraints play a role. In the process, I reveal that export demand shocks influence firms' expansion in terms of employment, wages, and investment. Finally, my quantification exercise indicates that export demand shocks explain about $1.4 \%$ of the annual variation in Turkish domestic sales on average. This figure, which shows heterogeneities at the sector level, rises to $4.6 \%$ during the Great Recession in 2009, when demand in Turkey's key export partners collapsed.
\end{abstract}

Keywords International trade $\cdot$ Domestic sales $\cdot$ Export shocks $\cdot$ Carry-along trade

JEL Classification F1 $\cdot$ F14 $\cdot$ F61 $\cdot$ L20

Aksel Erbahar

erbahar@ese.eur.nl

1 Erasmus School of Economics (ESE), Erasmus University Rotterdam, Rotterdam, The Netherlands

2 Tinbergen Institute, Amsterdam, The Netherlands 


\section{Introduction}

Exporters generally serve at least two markets: home and foreign. Traditional heterogeneous firms and trade models such as Melitz (2003) and Chaney (2008) predict no causal relationship between firms' exports and domestic sales in the shortrun (abstracting from general-equilibrium effects). By analyzing the relationship between sales in different markets at the firm-product level, this paper seeks to identify the channels that link exports and domestic sales. This question is important mainly due to two reasons. First, the traditional trade models' assumption of profit maximization with perfectly segmented markets and constant marginal costs might not be correct, leading to misleading trade liberalization effects on firm-level adjustments such as productivity gains. Second, understanding the link between firms' sales in different markets can help policymakers alleviate the negative consequences of cross-border business cycle transmissions.

To examine the mechanism that links firms' sales at home and abroad, I use a detailed dataset on Turkish firms for the 2005-2014 period that allows me to match firms' product-level sales data with product-level exports. First, I instrument firmlevel exports with destination-product-year specific imports from the world to proxy for exogenous demand shocks. I find that an exogenous $10 \%$ rise in exports increases a firm's domestic sales by $2.6 \%$ on average, confirming the findings of Berman et al. (2015) for French firms. However, unlike Berman et al. (2015), I find that this effect exists for Turkey's large firms as well, albeit with a lower magnitude when compared to the effect for small firms.

The finding that there is a positive causal relationship between sales in different markets is useful to predict aggregate firm-level sales dynamics, but it is not sufficient to understand the mechanism that transmits these shocks. The literature identifies three main channels that can explain the relationship between firms' sales in different markets: (i) capacity constraints at the firm-product level that would generate a negative relationship, (ii) liquidity constraints at the firm level that would generate a positive relationship, and (iii) efficiency gains that can be both at the firm and firm-product level that would generate a positive relationship. This type of efficiency or productivity gains is also known as "learning by exporting" in the heterogeneous firms and trade literature, whereby some firms increase their productivity once they begin exporting. In the short-run, this third channel is likely due to increasing returns to scale at the firm-product level, where an exogenous demand shock would cause the firm to move along its (non-constant) marginal cost curve. ${ }^{1}$

To identify the mechanism described above, I first differentiate between the firm and firm-product channels. In order to achieve this, I use firm-year fixed effects and examine the relationship between firms' sales in different markets at the firm-product level, and find coefficients that are almost twice as large as the ones found in the firm level regressions, hinting to the importance of product-specific scale effects.

\footnotetext{
1 In the long-run, the marginal cost curve can also shift downwards due to investment in more efficient technologies and/or management practices at the firm level. However, the long-run consequences of export demand shocks on firms is beyond the scope of this paper.
} 
This result is robust to a battery of sensitivity analyses using alternative controls, samples, and multiple instruments. Then, following Bernard et al. (2019), who show the prevalence of carry-along trade (CAT) for Belgian firms, I separate Turkish exporters' foreign sales into produced versus non-produced (or CAT) exports, and show that the complementary relationship is also due to CAT exports. Assuming that liquidity constraints operate at the firm level (not at the firm-product level), and that exogenous changes in CAT exports affect firms through a financial channel, combined with the finding that the relationship between sales is strongest for smaller firms suggest that spillovers at the firm level such as the easing of liquidity constraints also play a role. ${ }^{2}$ In the process, by examining produced and CAT exports separately, I propose a novel approach to isolate the production versus non-production factors that influence firm dynamics. Moreover, I show that export demand shocks influence firms' employment, wages per employee, and investment decisions as in Lileeva and Trefler (2010) and Bustos (2011). In the final part of the paper, I follow di Giovanni et al. (2018) and Héricourt and Nedoncelle (2018) to quantify the effect of exogenous export demand shocks at the aggregate level. My estimates indicate that variations in export demand can explain about $1.4 \%$ of the annual variation in Turkish domestic sales. This figure, which shows heterogeneities at the sector level, rises to $4.6 \%$ during the Great Recession in 2009, when demand in Turkey's key export partners collapsed and credit supply shrank.

This paper is mainly related to two strands of the heterogeneous firms and trade literature. First, it is related to the growing literature on the relationship between exports and domestic sales. Berman et al. (2015), using French firm-level data, find that firms' exports and domestic sales are complements, not substitutes. More precisely, they find that an exogenous $10 \%$ increase in a firm' exports increases its domestic sales by 1-3\% in the short-run. Even though they show suggestive evidence that the link between sales might be due to liquidity constraints, they cannot identify the precise channel since they do not observe sales at the firm-product level. Almunia et al. (2018), on the other hand, find that Spanish firms whose domestic sales were negatively affected by the Great Recession increased their exports, and explain this "venting-for-surplus" phenomenon by building a Melitz-type model with non-constant marginal costs. ${ }^{3}$ Bugamelli et al. (2015) use Italian firm-level data to find a business-cycle dependent correlation (not causation) between exports and domestic sales. Overall, these results are contrary to what is predicted by traditional trade models such as Melitz (2003) and Chaney (2008) which project that exogenous shocks to one export-market should have no effect on that firm's sales to other markets in the short-run. Other papers that examine the effects of foreign shocks on firms include Ekholm et al. (2012) who find that Norwegian firms that were more exposed to the appreciation of the Krone restructured manufacturing, and Hummels

\footnotetext{
${ }^{2}$ Manova (2013) highlights the importance of credit constraints in an international trade context by building on Melitz (2003). While she focuses on the effect of credit constraints on the extensive and intensive margins of exporting, I focus on the intensive margin of domestic operations.

3 Even though these papers' conclusions seem contradictory, they use different methodologies and examine different countries and time periods.
} 
et al. (2014) who find that positive export shocks caused Danish firms to pay higher wages. ${ }^{4}$ However, these papers are mostly silent about the channel of transmission as they lack firm-product data, and thus cannot observe product-market segmentation.

My paper first confirms the findings of Berman et al. (2015) at the firm level using a different context, and then contributes to the literature by finding that export demand shocks influence domestic sales positively at the firm-product level as well, with a larger magnitude. The firm-product specifications that shut down the firm factors by firm-year fixed effects reveal a strong link, and thus give support to scale effects. Nevertheless, the positive effect of CAT exports on domestic sales suggests that factors unrelated to production (e.g. liquidity constraints) also contribute to the link between sales in different markets. As revealed by the quantification exercise, the results are informative as in a world that is increasingly integrated through supply-chains, exogenous foreign demand shocks can have large spillover effects in home countries. When these shocks are negative, firms' sales to their home market can be adversely affected as well, hinting to policy recommendations that encourage product-market diversification.

Second, by analyzing the relationship between firms' sales in different markets, this paper is related to a growing literature that seeks to deduce firms' cost structures. Papers in this literature argue that the constant marginal cost assumption made by traditional trade models might not be correct due to, for example, capacity constraints which would entail increasing marginal costs. Vannoorenberghe (2012), Soderbery (2014), Ahn and McQuoid (2017), and Almunia et al. (2018) suggest that firms might have increasing marginal costs that generate a substitutable relationship between sales in different markets. A model with liquidity constraints, on the other hand, can produce a complementary relation between sales in different markets. This is what is proposed by Berman et al. (2015) as an explanation for their finding: an exogenous increase in exports allows the firm use the surplus cash-flow to expand domestic operations by causing a downward shift in the firm's marginal cost curve. Models of firm dynamics with liquidity constraints such as the ones developed by Cooley and Quadrini (2001) and Kohn et al. (2016) would also predict a positive relationship between exports and domestic sales due to cash flow fluctuations. ${ }^{5}$

The rest of the paper is organized as follows. Section 2 describes the data. In Sect. 3, I explain the empirical identification strategy to analyze the effect of export demand shocks on domestic sales, as well as the strategy to identify the channels that link firms' sales in different markets. Section 4 shows the results with robustness checks, and provides a quantification exercise. Finally, Sect. 5 concludes.

\footnotetext{
4 I confirm the findings of Hummels et al. (2014) and show that export demand shocks influence firms' average wages positively in Turkey-see Sect. 4.2.3.

5 This paper is also indirectly related to the vast literature on "learning by exporting." See, for example, De Loecker $(2007,2011,2013)$ who builds on the TFP estimation literature, and Atkin et al. (2017) who use a randomized experiment. Most papers in this literature examine the effect of exporting for the first time (extensive margin) on firm productivity, while my paper analyzes the effect of a change in exports (intensive margin) on domestic sales. Even though less likely in the short-run, one of the channels that can explain the relationship between sales is this "learning" effect.
} 


\section{Data}

I use three main datasets in this paper. First is the Industry and Services Statistics database which has annual firm-level statistics such as total sales, employment, wage bill, investment, and costs for each firm that has at least 20 employees for the period 2003-2014. ${ }^{6}$ I use this dataset mainly to infer firms' total domestic sales (by subtracting exports from total sales). The second dataset is the Foreign Trade Statistics database which is the customs data that reports exports and imports (both values and volumes) at the firm-country-product level for the 2002-2014 period. Products are classified at the 12-digit GTIP (Gümrük Tarife Istatistik Pozisyonu) level, but I aggregate the data to the internationally standardized 6-digit Harmonized Schedule (HS6) level for the empirical analysis. To make sure that the set of products are defined consistently over the sample period, I concord the trade data over time to the HS2007 nomenclature using Pierce and Schott's (2009) algorithm and the HS correspondence tables from the UN Statistics Division.

Most of the empirical international trade literature utilize the combination of the above mentioned two types of datasets. I use an additional unique dataset, Industry Production Statistics, that allows me to observe the value and volume of sales of each firm-product that is produced by a firm in Turkey for the 2005-2014 period. Products are classified according to the 10-digit PRODTR classification and are concorded over time by the Turkish Statistical Institute (TÜIK) to the 2010 classification. In order to match the production data, which is at the firm-PRODTR-year level, with the trade data, which is now aggregated to the firm-HS6-year level, I apply the algorithm developed by Van Beveren et al. (2012) to the PRODTR-HS6 correspondence tables provided by TÜIKK and create uniform HS6+ codes. These are codes that match one-to-one to HS6 codes as well as codes that include multiple HS6 codes to fix the issue of one-to-many and many-to-many PRODTR-HS6 matches. Combined with the over time concordance, this results in 2572 HS6+ products as opposed to 4622 HS6 products (in manufacturing).

Merging the three databases through unique firm IDs results in a sample of 21,926 manufacturers. Table 1 shows key summary statistics for this sample. ${ }^{7}$ Note that the average (median) export share (exports/sales) of exporters in the sample is $20(10) \%$. The majority of firms export $<10 \%$ of their sales and this share increases monotonically. This share is similar at the firm-product level when the set of products consists of goods produced and sold in both domestic and foreign markets. However, since I do not observe domestic sales of non-produced goods at the firmproduct level, it is not clear whether non-produced exported goods (CAT products) have a similar export share. I infer total domestic sales by subtracting total exports from total sales, and infer produced domestic sales by subtracting total produced exports from total produced sales. Also, note that the median firm is a single-good producer, but a multi-product exporter at the HS6+ level.

\footnotetext{
6 The database also includes firms that have $<20$ employees but these firms are not required to participate in the census, and thus are not consistently in the database for all years.

7 "Appendix 1" explains the data cleaning procedures.
} 
Table 1 Summary statistics, 2005-2014

\begin{tabular}{llll}
\hline & $\begin{array}{l}\text { Mean } \\
(1)\end{array}$ & $\begin{array}{l}\text { Median } \\
(2)\end{array}$ & $\begin{array}{l}\text { SD } \\
(3)\end{array}$ \\
\hline Export share & 0.20 & 0.10 & 0.24 \\
CAT share & 0.54 & 0.60 & 0.42 \\
Total sales & 51.75 & 8.80 & 434.78 \\
Total exports & 9.71 & 0.76 & 100.44 \\
Produced exports & 5.36 & 0.09 & 77.98 \\
Domestic sales & 42.04 & 6.70 & 372.41 \\
Produced domestic sales & 36.49 & 6.95 & 263.03 \\
Imports & 16.23 & 0.33 & 247.51 \\
Investment & 3.61 & 0.22 & 63.99 \\
Number of workers & 144 & 50 & 534 \\
Wages per worker & 15,712 & 11,913 & 12,627 \\
Number of produced HS6+ & 2.2 & 1 & 2.2 \\
Number of exported HS6+ & 9.3 & 4 & 17.3 \\
Number of markets & 8.0 & 4 & 10.4 \\
Number of HS6+ markets & 5.9 & 3 & 8.7 \\
\hline
\end{tabular}

The summary statistics are for the benchmark sample used in Table 3 column (1). The number of observations is 85,043 , with 21,926 unique firms. CAT share is the share of non-produced exports in total exports. Values of sales, exports, imports, and investment are in millions of Turkish liras. Wages per worker are in Turkish liras

It is important to emphasize the role of CAT in the Turkish economy as this will be crucial in identifying the non-production related factors that influence firms' domestic sales. As shown in Table 2, and similar to the findings of Bernard et al. (2019) for Belgian firms, I find that CAT is also prevalent in Turkey: $88 \%$ of manufacturing exporters export at least one good (HS6+) that they do not produce. In terms of value, $94 \%$ of exports came from firms that engaged in both produced and CAT exports. When compared to Belgium, CAT in Turkey, a large developing country, is more substantial in terms of value, as these exports make up $43 \%$ of manufacturing firm exports in 2010, as opposed to $30 \%$ that was found for Belgian firms in 2005 by Bernard et al. (2019). Moreover, CAT is not product-specific: $95 \%$ of HS6+ products were exported via CAT by at least one firm in 2010. Also, $79 \%$ of firmproduct observations were due to CAT. Informatively, these results hold when I use more aggregated levels of HS4+ and HS2+. Table 2 shows that CAT is prevalent regardless of aggregation-in fact, $68 \%$ of manufacturing exporters in 2010 had at least one CAT product even at the HS2+ level. ${ }^{8}$ It is important to point out that CAT is not driven by re-exports: dropping products (at the most disaggregate GTIP level) that the firm imports and exports in the same year does not change the results; in

\footnotetext{
${ }^{8}$ Note that even the HS6+ level is a conservative estimate of the prevalence of CAT since products are much more disaggregated in reality. Aggregation at the HS6+ level ensures that measurement error due to potential misclassification at more disaggregate levels is minimized.
} 
Table 2 CAT in 2010

Firms with at least 1 CAT product

Total products

Products exported as CAT by at least 1 firm

Firm-products

CAT firm-products

Share of CAT exports

\section{HS6+}

(1)

HS4+

(2)

7453

2610

2490

94,753

74,947

$43 \%$

6894

942
HS2+

(3)

80

79

33,598

22,305

$11 \%$

Statistics are based on the 8434 manufacturing exporters in 2010. These statistics are cross-sectional and thus do not incorporate over time concordance of products

fact, the median exporter does not engage in re-exports. Also, in order to make sure that CAT is not driven by inventories or a partial-year effect as discussed by Bernard et al. (2017), I define CAT as exported but not produced for three-consecutive years, and the pervasiveness of CAT holds. ${ }^{9}$ Other papers that show the ubiquity of CAT include Abreha et al. (2013), Di Nino (2015), Arnarson (2016), and van den Berg et al. (2019) for Danish, Italian, Swedish, and Dutch firms respectively.

For the construction of the instruments and the controls, I use trade data from UN Comtrade and tariff data from UNCTAD's TRAINS.

\section{Identification strategy}

In this section, I present the methodology used to examine whether exogenous export demand shocks have an effect on firms' domestic sales. Note that there might be reverse causality between a firm's domestic sales and exports. For instance, an exogenous demand shock at home that affects domestic sales can also have spillover effects on firms' exports in the short-run. Moreover, since domestic sales is calculated by subtracting exports from total sales, misreporting of exports mechanically affects the domestic sales variable, creating non-classical measurement error. ${ }^{10}$ Thus, to be able to account for both reverse causality and measurement error, the identification strategy relies on instrumenting exports. This makes sure that the variation in exports comes only from exogenous sources, which are orthogonal to the error in exports. In fact, Appendix Table 10 shows that the OLS coefficients on exports are generally either positive but relatively small in magnitude or not significantly different from zero. This attenuation can be explained largely by the error-invariables bias. ${ }^{11}$

\footnotetext{
${ }^{9}$ These results are available on request.

${ }^{10}$ The online appendix of Berman et al. (2015) formalizes this point.

11 There might be other reasons for this negative bias in the OLS coefficient such as the firm's substitution of indirect versus direct exporting if domestic sales include indirect exports.
} 
As a preliminary step, I first run the 2SLS regressions at the firm level. Then, I turn to the main contribution of this paper and dig deeper by (i) examining the relationship at the firm-product level, and (ii) separating exports into produced versus CAT exports to illuminate the channel.

\subsection{At the firm level}

The first and second stages of the firm-level regressions respectively are:

$$
\begin{gathered}
\ln X_{i t}=\alpha \ln F D_{i t}+\theta \ln D D_{i t}+\mu_{i}+\delta_{n t}+v_{i t}, \\
\ln Y_{i t}=\beta \widehat{\ln X_{i t}}+\gamma \ln D D_{i t}+\mu_{i}+\delta_{n t}+\epsilon_{i t},
\end{gathered}
$$

where $\ln Y_{i t}$ is domestic sales of firm $i$ in year $t, \widehat{\ln X_{i t}}$ is the predicted value of $\log$ exports from equation (1), $\mu_{i}$ and $\delta_{n t}$ are firm and sector-year fixed effects $(F E)$ respectively, and $v_{i t}$ and $\epsilon_{i t}$ are errors that are potentially correlated within sectors. ${ }^{12}$ Throughout all firm-level regressions, I use firm $F E$ to examine within-firm variation in sales, and sector-year $F E$ to control for sector-wide supply and demand shocks (and price levels) that might drive exports and domestic sales simultaneously.

The identification strategy relies on an exogenous demand shock in the importing country boosting the firm's exports. For this, I follow the methodology proposed by Hummels et al. (2014) and Berman et al. (2015), and instrument exports with the following foreign demand, or $F D$ :

$$
F D_{i t}=\sum_{c h} \omega_{i c h}(\text { imports })_{c h t},
$$

where $\omega_{i c h}$ is the average weight of a country-product $c h$ in firm $i$ 's total exports in 2005-2014, and imports are importing-country-product-year (cht) specific (and excludes imports from Turkey). This instrument is meant to proxy for a shift in the import demand curve of product-markets that the firm serves. ${ }^{13}$ In most settings, the instrument is a strong predictor of firm exports, and satisfies the exclusion restriction since another country's imports from the rest of the world is assumed to be exogenous to a single firm in a third-country. Still, demand shocks might be correlated across countries; thus, I control for Turkey's product-specific (import) demand with the following domestic demand variable, or $D D$ :

$$
D D_{i t}=\sum_{h} \eta_{i h} \text { (imports) }{ }_{T U R, h t}
$$

where $\eta_{i h}$ is the average weight of a product in a firm's total exports in 2005-2014,

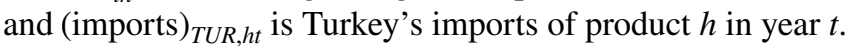

\footnotetext{
12 There are 62 2-digit NACE (Nomenclature Statistique des Activités Économiques dans la Communauté Européenne) sectors, self-reported as their primary industry by firms.

13 This type of exogenous demand shock proxy is widely used in the heterogeneous firms and trade literature, including how it affects firms' product allocation as in Mayer et al. (2016).
} 
As an alternative dependent variable, I use produced domestic sales (domestic sales of products that are produced by the firm itself), which is simply total produced sales minus total produced exports. As shown in Table 1, firms also have domestic CAT sales. ${ }^{14}$ This differentiation is important to get a glimpse at whether the underlying mechanism between sales in different markets is via production synergies. I estimate the above system using 2SLS and cluster standard errors by sectors. Looking at equation (2), a negative and significant $\beta$ coefficient would support the capacity constraints hypothesis, whereas a positive and significant $\beta$ would reveal that the relationship is due to liquidity constraints and/or efficiency gains.

Note that especially for the liquidity constraint channel, it is crucial that the effect is symmetric. In other words, a credit-constrained firm whose export cash flow is negatively affected should be as likely to alter its domestic operations as when its export cash flow gets a boost. To check for this, I interact the exports variable with a dummy that indicates whether the exports have risen over the previous year. Also, since smaller firms are more likely to be credit constrained, I run additional regressions by interacting the exports variable with the firm's initial size in terms of employment (demeaned, so that the main effect corresponds to the average-sized firm), as well as quartile size bins.

\subsection{Identifying the channel}

There are three main mechanisms that can generate a relationship between firms' sales in different markets. I describe them below, and explain in detail how my methodology can identify them in the following subsections.

The first, and perhaps the most obvious, channel is capacity constraints. This channel would predict a negative relationship between sales at home and abroad as firms would have to cut back in other markets in order to serve the expanding market (or boost sales in other markets in order to compensate for the declining market: "venting-for-surplus"). Theoretically, this type of relationship, which is likely to be strongest in the short-run, can be generated with a model with increasing marginal costs as in Vannoorenberghe (2012), Soderbery (2014), Ahn and McQuoid (2017), and Almunia et al. (2018). I test for this channel by shutting down firm factors and examining the relationship at the firm-product level, where capacity constraints would play a large role.

The second channel is liquidity constraints whereby an exogenous increase in exports would provide the firm with extra cash flow to expand domestic operations. In addition, these extra exports can allow the firm to get credit (or cheaper credit) by using exports as collateral. This channel predicts a positive relationship between sales in different markets, and is especially important for small firms who are likely

\footnotetext{
14 Since I do not observe non-produced domestic sales at the product-level, these domestic CAT sales might also include non-manufactured goods such as agricultural products and services. Nevertheless, the overwhelming majority of these firms' self-reported main industry is manufacturing, which implies that non-manufacturing activities do not constitute a sizable share of total sales. In fact, the data shows that the median share of produced domestic sales in total domestic sales is $95 \%$.
} 
to be more credit constrained, ${ }^{15}$ particularly in a developing country like Turkey where "access to finance" was chosen as one of the top obstacles to business according to the The World Bank's (2013) Enterprise Surveys on Turkey. Theoretically, this type of transmission mechanism can be generated by dynamic firm models with financial frictions such as the ones developed by Cooley and Quadrini (2001) and Kohn et al. (2016). I test for this mechanism by separating produced versus nonproduced (or CAT) exports, and examine the differential effect at the firm level. This novel approach is advantageous as it allows me to focus on an exogenous change in cash flow that is not related to production. Thus, finding a positive link between a firm's CAT exports and domestic sales would imply that the mechanism can at least be partly explained by the easing of liquidity constraints. The underlying assumption here is that liquidity constraints are at the firm level (not at the firm-product level) as firms can shuffle resources from one production activity to another.

The third channel is efficiency or productivity gains through exporting, also known as "learning by exporting." This can be both at the firm and firm-product level, and it would generate a positive relationship between exports and domestic sales, as an exogenous increase in exports would cause the firm to become more efficient. This paper is chiefly interested in the short-run relationship between exports and domestic sales, where this learning can be characterized by firm-product-specific efficiency gains through scale effects (moving along the marginal cost curve). I test for this channel by examining the relationship at the firm-product level. Also, to get a glimpse at how the firm uses the extra cash, I analyze the effect of exogenous export demand shocks on firms' employment, wages per employee, and investment. Positive links between exogenous changes in cash flow and these variables would indicate that the previously constrained firm is now able to expand to reach its optimal size.

\subsubsection{At the firm-product level}

In order to see whether capacity constraints or product-specific efficiency gains play a role, and since the majority of firms produce and export multiple products $(88 \%$ of manufacturing firms in 2010), I now turn to regressions at the more disaggregate firm-product level. Note that in these estimations, products that are sold exclusively to the domestic market or exported à la CAT are dropped. Thus, I am only examining firm-products that are produced and sold both domestically and abroad.

The first and second stages for the firm-product regressions are:

$$
\begin{gathered}
\ln X_{i h t}=\alpha \ln F D_{i h t}+\theta \ln D D_{h t}+\phi_{H S 2 t}+\mu_{i h}+\delta_{i t}+v_{i h t}, \\
\ln Y_{i h t}=\beta \widehat{\ln X_{i h t}}+\gamma \ln D D_{h t}+\phi_{H S 2 t}+\mu_{i h}+\delta_{i t}+\epsilon_{i h t},
\end{gathered}
$$

\footnotetext{
15 Among others, Beck et al. (2005) and Forbes (2007) show that smaller firms face tighter credit constraints.
} 
where $\ln Y_{i h t}$ is domestic sales of firm $i$ product $h$ (classified at the HS6+ level as described in Sect. 2) in year $t, \widehat{\ln X_{i h t}}$ is the predicted value of $\log$ exports from equation (3), $\phi_{H S 2 t}, \mu_{i h}$ and $\delta_{i t}$ are HS2-year, firm-product, and firm-year FE respectively, and $v_{i h t}$ and $\epsilon_{i h t}$ are errors that are potentially correlated within firm observations. I use HS2-year $F E$ to control for sector-specific supply and demand shocks (and price levels), firm-product $F E$ to partial-out inherent firm-product efficiency, and firmyear $F E$ to control for time-varying firm productivity. Including firm-year $F E$ means that the identification relies on multi-product producers' sales variation. Moreover, it allows me to shut down time-varying firm factors such as liquidity constraints and managerial efficiency, and pinpoint the transmission mechanism. I estimate the above system using 2SLS, clustering standard errors by firms. ${ }^{16}$

The instrument for export sales is now given by:

$$
F D_{i h t}=\sum_{c} \omega_{i c h}(\text { imports })_{c h t},
$$

where $\omega_{i c h}$ is the average weight of a country in a firm's total exports of a product in 2005-2014, and imports are importing-country-product-year specific (and excludes imports from Turkey). Like before, to control for correlated demand shocks, I include Turkey's (import) demand in the second-stage with the domestic demand $\left(D D_{h t}\right)$ variable that is proxied by Turkey's imports of product $h .^{17}$ If the estimated $\beta$ is negative, then capacity constraints play a role; if it is positive, then the culprit is product-specific efficiency gains through scale effects. ${ }^{18}$ Taking advantage of the dataset's richness, and since imports might not pick up domestic demand fluctuations perfectly, I also use an alternative proxy variable based on non-exporters' product-specific sales (which are by definition all domestic sales). ${ }^{19}$ Section 4.2.1 describes several more robustness checks, including using an additional instrument based on destination-product MFN tariffs to test for over-identifying restrictions. The tariff instrument, which is assumed to be exogenous to firms in Turkey, is constructed analogous to the main instrument as detailed in "Appendix 2".

\subsubsection{Produced and CAT exports separated}

The methodology described above in Sect. 3.2.1 excludes non-produced (CAT) exports. In this section, I focus on the effect of a change in a firm's CAT exports which proxies for a change in cash flow (or equivalently liquidity constraint). Importantly, a change in CAT exports should not affect the physical productivity (or

\footnotetext{
16 An alternative strategy by clustering multi-way at the firm and HS6+ level to control for correlated errors along multiple non-nested groups (as suggested by Cameron et al. 2011) is also presented.

17 The raw correlation between $\ln Y_{i h t}$ and $\ln F D_{i h t}$ is 0.01 .

18 Note that if export demand shocks were serially negatively correlated, then firms would be able to cushion against shocks using their inventories. However, the data shows that $\ln F D_{i h t}$ is serially positively correlated (correlation between $\ln F D_{i h t}$ and its lag is 0.98 ), which mitigates this concern.

19 Note that to get a consistent $\beta$ coefficient, the domestic demand variable is necessary only to control for the part of the domestic demand shock that is correlated with the export demand shock. Thus, it does not need to perfectly capture domestic demand conditions.
} 
manufacturing ability) of the firm. Thus, the underlying assumption here is that CAT exports influence a firm's domestic sales only through a liquidity channel. A positive and significant coefficient on produced exports would support the hypothesis that the complementarity is due to efficiency gains through scale effects, whereas a positive and significant coefficient on CAT exports would imply that the complementarity is due to firm-level spillovers such as the easing of liquidity constraints. ${ }^{20}$

Here, I construct $F D_{i t}$ that are specific for produced and CAT exports to get $F D P_{i t}$ and $F D C_{i t}$ respectively, and estimate separate 2 SLS regressions for produced versus CAT exports. I do not include both types of exports in the same specification as the instruments $F D P_{i t}$ and $F D C_{i t}$ are highly correlated (0.45), resulting in substantial efficiency loss.

\section{Results}

\subsection{Results for the firm level}

Table 3 shows the 2 SLS results. The first two columns have total domestic sales as the dependent variable. Column (1) shows that an exogenous $10 \%$ rise in exports increases a firm's domestic sales by $2.2 \%$, larger than the magnitude of $1.4 \%$ found for French firms by Berman et al. (2015). In benchmark column (2), since imports are certainly related to domestic sales and possibly correlated with export demand shocks, I control for firm imports, and find a similar coefficient at the magnitude of $2.6 \% .^{21}$ Columns (3) and (4) use produced domestic sales as the dependent variable and show similar results, indicating that the effect goes through the firm's domestic sales of "own" goods. The $F$ stat version of the Kleibergen-Paap (KP) statistic shows that the instrument is strong as the KP stats are higher than the critical value of 16.4 based on a $10 \%$ maximal IV size in all columns. Overall, these results already rule out that capacity constraints are the driving force behind the exportsdomestic sales relationship. ${ }^{22}$

Appendix Table 11 shows that the results in Table 3 are robust to using initial weights in constructing the instrument, having an alternative domestic demand proxy based on non-exporters' domestic sales, excluding firms that serve only one destination, focusing on firms whose imports make up a small share of their material

\footnotetext{
${ }^{20}$ Alternatively, a negative and significant coefficient on produced exports (but not on CAT exports) would give support to capacity constraints.

21 In unreported results, I follow the online appendix of Berman et al. (2015) and instrument firm-level imports with an analogously defined IV (based on countries' exports to the rest of the world) and find that the two instruments are not jointly strong enough for statistical inference (KP-stat: 8.54). This is possibly due to the high correlation between the two instruments, creating collinearity. An alternative way to make sure that firm-level imports are not confounding the results is to restrict the sample to non-importers. However, this results in losing more than three-quarters of observations and the instrument becomes too weak for statistical inference (KP-stat.: 0.84).

22 In unreported results, I find that the effect is larger for firms with higher export shares (exports/sales), revealing that sales synergies occur more intensely when exports make a non-negligible share of firms' sales.
} 
Table 3 Effect of export demand shocks at the firm level

\begin{tabular}{|c|c|c|c|c|}
\hline \multirow[t]{2}{*}{ Dep. variable } & \multicolumn{2}{|c|}{ In total domestic sales ${ }_{i t}$} & \multicolumn{2}{|c|}{$\begin{array}{l}\text { In produced domestic } \\
\text { sales }_{\text {it }}\end{array}$} \\
\hline & (1) & (2) & (3) & (4) \\
\hline $\ln$ exports $_{i t}$ & $\begin{array}{l}0.218 * * * \\
(0.063)\end{array}$ & $\begin{array}{l}0.256 * * * \\
(0.075)\end{array}$ & $\begin{array}{l}0.238 * * * \\
(0.059)\end{array}$ & $\begin{array}{l}0.232^{* *} \\
(0.091)\end{array}$ \\
\hline $\ln D D_{i t}$ & $\begin{array}{l}0.044 \\
(0.029)\end{array}$ & $\begin{array}{l}0.034 \\
(0.032)\end{array}$ & $\begin{array}{l}0.027 \\
(0.025)\end{array}$ & $\begin{array}{l}0.018 \\
(0.030)\end{array}$ \\
\hline $\ln _{\text {imports }}{ }_{i t}$ & & $\begin{array}{l}0.040 * * * \\
(0.012)\end{array}$ & & $\begin{array}{l}0.053 * * * \\
(0.013)\end{array}$ \\
\hline \multicolumn{5}{|l|}{ First-stage } \\
\hline $\ln F D_{i t}$ & $\begin{array}{l}0.094 * * * \\
(0.019)\end{array}$ & $\begin{array}{l}0.080 * * * \\
(0.015)\end{array}$ & $\begin{array}{l}0.095 * * * \\
(0.019)\end{array}$ & $\begin{array}{l}0.081 * * * \\
(0.019)\end{array}$ \\
\hline $\ln D D_{i t}$ & $\begin{array}{l}-0.021 \\
(0.025)\end{array}$ & $\begin{array}{l}-0.009 \\
(0.029)\end{array}$ & $\begin{array}{l}-0.020 \\
(0.025)\end{array}$ & $\begin{array}{l}-0.009 \\
(0.032)\end{array}$ \\
\hline $\operatorname{ln~imports~}_{i t}$ & & $\begin{array}{l}0.138 * * * \\
(0.007)\end{array}$ & & $\begin{array}{l}0.137 * * * \\
(0.006)\end{array}$ \\
\hline Observations & 85,043 & 65,496 & 84,917 & 65,409 \\
\hline$R^{2}$ & 0.91 & 0.91 & 0.92 & 0.92 \\
\hline KP-stat. & 23.50 & 27.03 & 23.84 & 27.87 \\
\hline
\end{tabular}

Standard errors clustered by sectors (2-digit NACE) are in parentheses. All regressions are estimated with 2SLS and include firm and sector-year fixed effects. The critical value of the Kleibergen-Paap (KP) statistic based on a $10 \%$ maximal IV size is 16.38

$* * *, * *, *$ Statistical significance at the 1,5 , and $10 \%$ levels respectively

costs (less than the median value of $4.5 \%$ ), as well as including an additional instrument based on tariffs. ${ }^{23}$ One might also be concerned that if Turkish exporters have substantial market power in a specific market, then the instrument might not satisfy the exclusion restriction. To dispel this concern, I compute the instrument by excluding destination-product markets where Turkey's share of exports is at least 50\% (or alternatively at least $10 \%$ ). Appendix Table 13 shows that results stay robust.

Is the positive relationship between sales at home and abroad symmetric, or in other words, does the effect depend on whether there is an increase or a decrease in exports? Table 4 column (1) shows that the relationship is symmetric, with positive growth having a slightly lower effect in magnitude. Column (4) has produced domestic sales as the dependent variable and confirms the results. The finding that the relationship is positive and symmetric gives support to liquidity constraints and/ or product-specific scale effects. Both positive and negative changes in cash flow would affect a firm either directly by altering its working capital or indirectly by changing is borrowing ability. Similarly, increasing returns to scale at the product

\footnotetext{
23 Appendix Table 12 has the corresponding first-stage results.
} 
Table 4 Direction of export growth and firm size

\begin{tabular}{|c|c|c|c|c|c|c|}
\hline \multirow[t]{2}{*}{ Dep. variable } & \multicolumn{3}{|c|}{ ln total domestic sales ${ }_{i t}$} & \multicolumn{3}{|c|}{ In produced domestic sales ${ }_{i t}$} \\
\hline & (1) & (2) & (3) & (4) & (5) & (6) \\
\hline $\ln _{\text {exports }}{ }_{i t}$ & $\begin{array}{l}0.385 * * * \\
(0.118)\end{array}$ & $\begin{array}{l}0.250 * * * \\
(0.073)\end{array}$ & $\begin{array}{l}0.389 * * * \\
(0.084)\end{array}$ & $\begin{array}{l}0.374 * * \\
(0.095)\end{array}$ & $\begin{array}{l}0.227 * * \\
(0.089)\end{array}$ & $\begin{array}{l}0.340 * * * \\
(0.091)\end{array}$ \\
\hline$\times(+)$ export growth ${ }_{i t}$ & $\begin{array}{l}-0.025^{* * * *} \\
(0.007)\end{array}$ & & & $\begin{array}{l}-0.021 * * * \\
(0.006)\end{array}$ & & \\
\hline$\times \ln$ employment $_{i}$ & & $\begin{array}{l}-0.001 \% \\
(0.000)\end{array}$ & & & $\begin{array}{l}-0.001 \\
(0.000)\end{array}$ & \\
\hline$\times Q 2_{i}$ & & & $\begin{array}{l}-0.113 \\
(0.069)\end{array}$ & & & $\begin{array}{l}-0.065 \\
(0.072)\end{array}$ \\
\hline$\times Q 3_{i}$ & & & $\begin{array}{l}-0.102 \\
(0.071)\end{array}$ & & & $\begin{array}{l}-0.089 \\
(0.062)\end{array}$ \\
\hline$\times Q 4_{i}$ & & & $\begin{array}{l}-0.213^{* * * *} \\
(0.065)\end{array}$ & & & $\begin{array}{l}-0.180 * * * \\
(0.058)\end{array}$ \\
\hline $\ln D D_{i t}$ & $\begin{array}{l}0.035 \\
(0.035)\end{array}$ & $\begin{array}{l}0.032 \\
(0.032)\end{array}$ & $\begin{array}{l}0.031 \\
(0.033)\end{array}$ & $\begin{array}{l}0.028 \\
(0.034)\end{array}$ & $\begin{array}{l}0.016 \\
(0.030)\end{array}$ & $\begin{array}{l}0.014 \\
(0.032)\end{array}$ \\
\hline $\operatorname{ln~imports~}_{i t}$ & $\begin{array}{l}0.024 \\
(0.016)\end{array}$ & $\begin{array}{l}0.041 * * * \\
(0.012)\end{array}$ & $\begin{array}{l}0.038 * * * \\
(0.011)\end{array}$ & $\begin{array}{l}0.033 * * * \\
(0.012)\end{array}$ & $\begin{array}{l}0.054 * * * \\
(0.013)\end{array}$ & $\begin{array}{l}0.051 * * * \\
(0.012)\end{array}$ \\
\hline Observations & 44,383 & 65,496 & 65,496 & 44,325 & 65,409 & 65,409 \\
\hline$R^{2}$ & 0.91 & 0.91 & 0.90 & 0.91 & 0.92 & 0.92 \\
\hline KP-stat. & 16.13 & 13.37 & 6.35 & 15.95 & 13.77 & 6.61 \\
\hline
\end{tabular}

(+) export growth ${ }_{i t}$ is a binary variable that is 1 if the firm's exports has increased over the previous year; ln employment ${ }_{i}$ is the demeaned initial employment level of firm $i ; Q 2_{i}, Q 3_{i}$, and $Q 4_{i}$ refer to quartile size bins based on ln employment ${ }_{i}\left(Q 1_{i}\right.$ is the omitted group). Standard errors clustered by sectors (2-digit NACE) are in parentheses. All regressions are estimated with 2SLS and include firm and sector-year fixed effects. The critical value of the Kleibergen-Paap (KP) statistic based on a 10\% maximal IV size is 7.03

$* * *, * *, *$ Statistical significance at the 1,5 , and $10 \%$ levels respectively

level would indicate that exogenous changes in demand might push the firm into higher or lower segments of the marginal cost curve. On the other hand, the positive and symmetric finding diminishes the role of capacity constraints or "learning by exporting" as drivers of the link between exports and domestic sales. Capacity constraints should have generated a negative coefficient only for positive exogenous changes in exports. The learning by exporting hypothesis argues that exporting activity causes the firm to be more productive, but it does not claim that decreased exporting activity would cause the firm to be less productive, making the relationship direction-specific.

Does firm size in terms of employment play a role? The literature indicates that small firms are more likely to be credit constrained, and thus the liquidity constraint channel is undoubtedly more important for them. Table 4 column (2) indicates that firms benefit from the complementary relationship regardless of size. However, the interaction coefficient is negative, suggesting that the effect diminishes for larger firms. In column 
(3), I separate the firms into quartile bins based on their initial size. The results suggest that the effect is strongest for firms in the first quartile, and is about half as large for the firms in the fourth quartile. ${ }^{24}$ This is in line with the hypothesis that small firms have more to gain from extra cash flow to expand their domestic operations. Columns (5) and (6) with produced domestic sales show similar results. Even though the direction of the effects for firm size is similar to the findings of Berman et al. (2015), they find no effect for large firms in France, whereas my findings indicate that large firms' domestic sales in Turkey are still substantially affected by export demand shocks. ${ }^{25}$ Overall, the results in this section corroborate that the relationship is complementary. The next section aims to shed light on these findings, and identify the channels that link sales.

\subsection{What are the mechanisms that link exports and domestic sales?}

\subsubsection{Results for the firm-product level}

Thus far, the results have shown that an exogenous demand shock to exports affects domestic sales positively at the firm level. In this section, in order to illuminate the channels, I focus on the relationship between exports and domestic sales at the firmproduct level.

Table 5 shows the results. In column (1), I use firm-product and HS2-year FE, and thus do not control for time-varying firm-level factors such as liquidity constraints. The coefficient is 0.31 , not too different from the one found in the firm-level regressions. However, the coefficient on exports in column (2), where all firm factors (including imports) are controlled with firm-year $F E$, indicates that an exogenous $10 \%$ rise in exports of a firm's product increases the domestic sales of that specific product by $4.7 \%$ - this is nearly twice as large as the $2.6 \%$ effect found at the firm level in Table 3 column (2). Note the use of strict $F E$ here, indicating that the only variation I am examining is the time-variation within a firm-product for multiproduct firms that sell the same HS6+ to both markets. In column (3), I multi-cluster the standard errors by firms and products to control for correlated product shocks. In column (4), I use an alternative domestic demand proxy based on non-exporters' sales. In column (5), I use initial instead of average weights in constructing the instrument.

Column (6) of Table 5 uses lagged exports (with lagged instrument $F D$ ), revealing that the positive effects are not limited to contemporaneous one-time shocks.

\footnotetext{
${ }^{24}$ Interacting with the median firm size, or by decile bins as proposed by Berman et al. (2012) produce similar results.

25 In unreported results, I interact exports with a dummy indicating whether the 2-digit NACE sector is credit-dependent. For this, I use Rajan and Zingales (1998) measures of external finance dependence and asset tangibility (also used by Manova 2013), and separate industries into two groups based on the median of the relevant measure. Regression results show that the interaction is not statistically significant, and thus the positive relationship is not driven by credit-dependent sectors- these results are available upon request.
} 


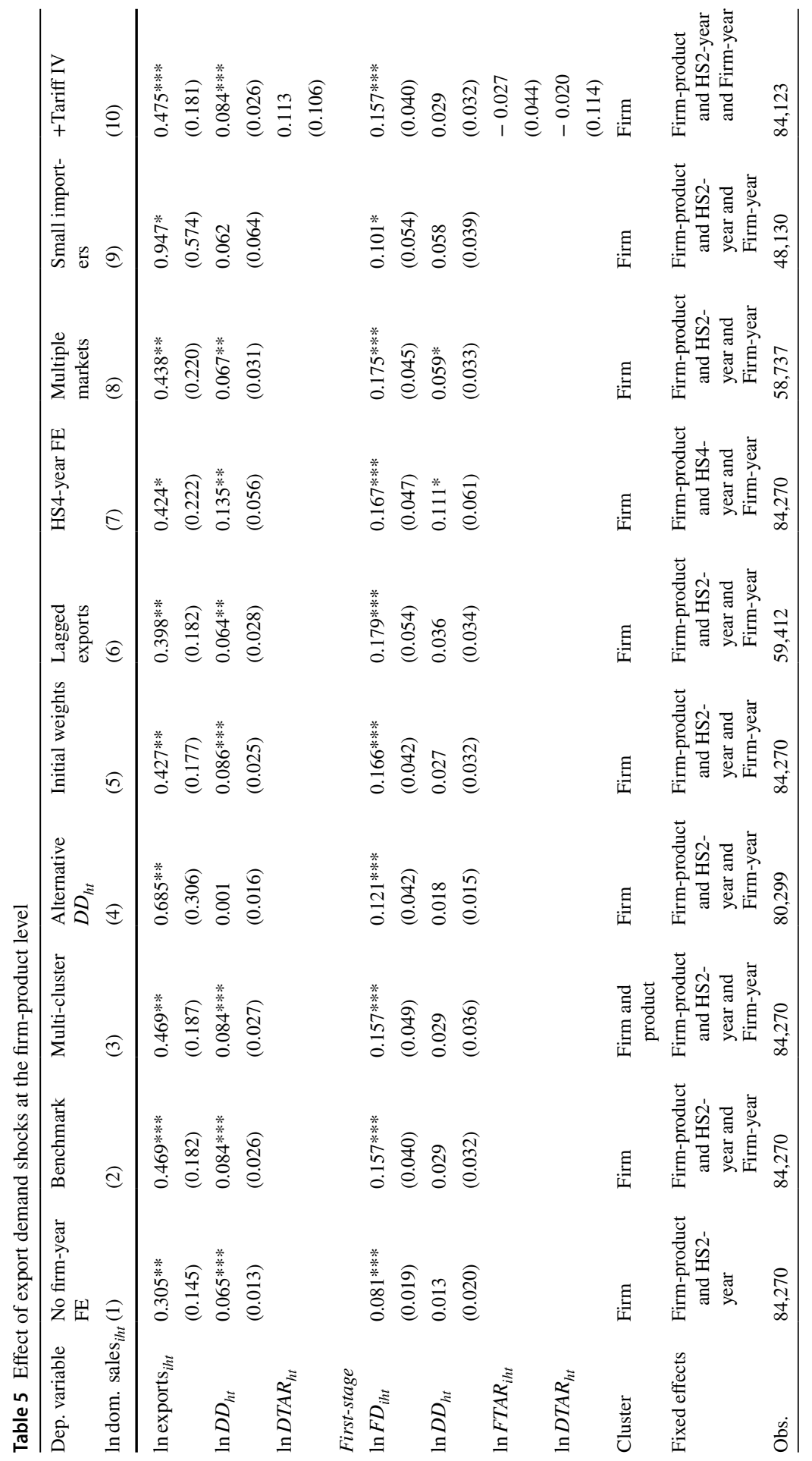




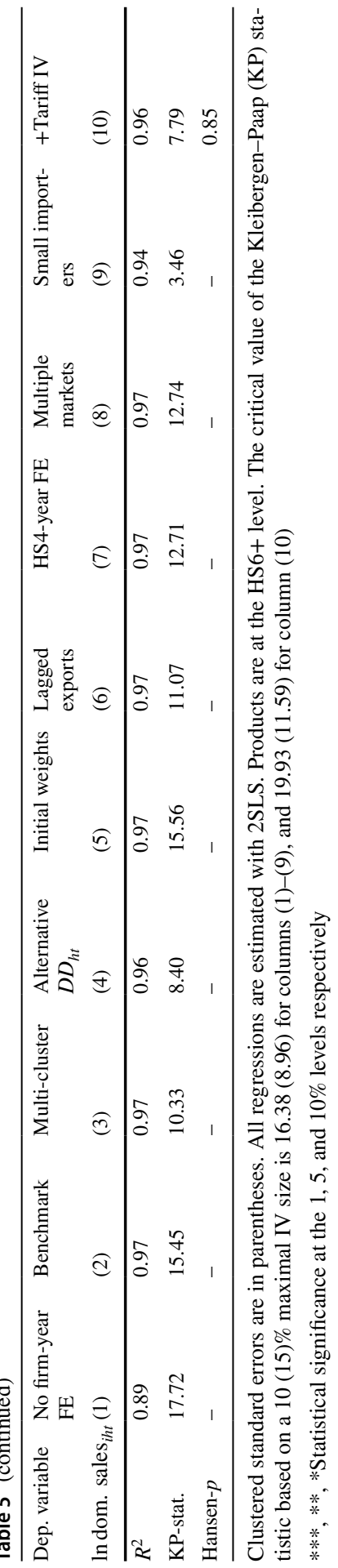


In column (7), I add HS4-year fixed effects to control for potentially correlated (among foreign and domestic) more disaggregate sector-level shocks. Column (8) excludes firm-products that are sold only to a single export destination. In column (9), I restrict the sample to small importers whose share of imports in material costs is less than the median value of $4.5 \%$. Finally, column (10) uses tariffs as the second instrument. In short, none of these robustness checks change the results qualitatively. Importantly, the Hansen $p$-value in column (10) is higher than 0.10 , indicating that the over-identification test cannot reject that the instruments are exogenous. The much larger coefficients generated from firm-product level regressions relative to the ones at the firm level suggest that the main link between sales at home and abroad in the short-run is product-specific efficiency gains through scale effects.

In order to check whether firm-product results are driven by scale-intensive sectors, I use Diewert and Fox's (2008) returns-to-scale estimations by SIC (Standard Industrial Classification) sector. They use US data and show robustly that nine out of the 18 manufacturing industries exhibit increasing returns to scale, whereas for the remaining industries constant returns to scale cannot be rejected. I match the SIC industries to HS6+ products by using the crosswalks between SIC-NACE and NACE-HS6 concordance files. In unreported results, I interact exports with a dummy that indicates whether the HS6+ is scale-intensive. These regressions show that the main effect is positive and significant, but the interaction is not statistically significant, revealing that the positive relationship is not driven solely by scaleintensive products. ${ }^{26}$

\subsubsection{Produced and CAT exports separated}

In Table 6, the first two columns regress total domestic sales on produced and CAT exports, and the last two columns regress produced domestic sales on produced and CAT exports. Columns (1) and (2) show that produced exports increase total domestic sales, whereas CAT exports seem to have a positive albeit insignificant relationship with total domestic sales. Comparing columns (3) and (4) reveals that the positive relationship between produced domestic sales and exports at the firm level is largely due to the non-produced (or CAT) portion of exports, as produced exports loses its significance (and magnitude) in column (3), and the CAT exports coefficient is significant and large in magnitude. It is surprising that produced exports do not affect produced domestic sales. Combined with the earlier positive firm-product level findings, this result might be due to firms selling a different mix of produced products domestically and abroad, and thus an exogenous change in a particular product's exports might induce a multi-product firm to reallocate resources into high-performing products. Overall, the positive and significant coefficient on CAT in column (4) indicates that non-production factors such as liquidity constraints also contribute to the relationship between exports and domestic sales. Note that the KP statistics are lower than the critical value of 16.4 in these regressions and thus the results should be interpreted with caution.

${ }^{26}$ These results are available upon request. 
Table 6 Produced and CAT exports separated

\begin{tabular}{|c|c|c|c|c|}
\hline \multirow[t]{2}{*}{ Dep. variable } & \multicolumn{2}{|c|}{$\begin{array}{l}\text { In total domestic } \\
\text { sales }_{\text {it }}\end{array}$} & \multicolumn{2}{|c|}{$\begin{array}{l}\text { In prod. domestic } \\
\text { sales }_{\text {it }}\end{array}$} \\
\hline & (1) & (2) & (3) & (4) \\
\hline In produced exports ${ }_{i t}$ & $\begin{array}{l}0.138 * \\
(0.073)\end{array}$ & & $\begin{array}{l}0.036 \\
(0.067)\end{array}$ & \\
\hline ln CAT exports ${ }_{i t}$ & & $\begin{array}{l}0.231 \\
(0.162)\end{array}$ & & $\begin{array}{l}0.454 * \\
(0.256)\end{array}$ \\
\hline $\ln D D_{i t}$ & $\begin{array}{l}0.030 \\
(0.037)\end{array}$ & $\begin{array}{l}0.050 \\
(0.033)\end{array}$ & $\begin{array}{l}0.013 \\
(0.037)\end{array}$ & $\begin{array}{l}0.031 \\
(0.036)\end{array}$ \\
\hline $\operatorname{ln~imports}_{i t}$ & $\begin{array}{l}0.057 * * * \\
(0.010)\end{array}$ & $\begin{array}{l}0.047 * * \\
(0.022)\end{array}$ & $\begin{array}{l}0.078 * * * \\
(0.009)\end{array}$ & $\begin{array}{l}0.029 \\
(0.033)\end{array}$ \\
\hline \multicolumn{5}{|l|}{ First-stage } \\
\hline $\ln F D P_{i t}$ & $\begin{array}{l}0.098 * * \\
(0.037)\end{array}$ & & $\begin{array}{l}0.100 * * * \\
(0.037)\end{array}$ & \\
\hline $\ln F D C_{i t}$ & & $\begin{array}{l}0.075 * * \\
(0.030)\end{array}$ & & $\begin{array}{l}0.069 * * \\
(0.030)\end{array}$ \\
\hline $\ln D D_{i t}$ & $\begin{array}{l}-0.002 \\
(0.048)\end{array}$ & $\begin{array}{l}0.000 \\
(0.053)\end{array}$ & $\begin{array}{l}-0.000 \\
(0.048)\end{array}$ & $\begin{array}{l}-0.007 \\
(0.054)\end{array}$ \\
\hline $\operatorname{ln~imports~}_{i t}$ & $\begin{array}{l}0.119 * * * \\
(0.009)\end{array}$ & $\begin{array}{l}0.131 * * * \\
(0.008)\end{array}$ & $\begin{array}{l}0.119 * * * \\
(0.009)\end{array}$ & $\begin{array}{l}0.130 * * * \\
(0.008)\end{array}$ \\
\hline Observations & 45,633 & 58,860 & 45,550 & 58,791 \\
\hline$R^{2}$ & 0.93 & 0.91 & 0.95 & 0.82 \\
\hline KP-stat. & 6.93 & 6.32 & 7.29 & 5.11 \\
\hline
\end{tabular}

Standard errors clustered by sectors (2-digit NACE) are in parentheses. All regressions are estimated with 2SLS and include firm and sector-year fixed effects. The critical value of the Kleibergen-Paap (KP) statistic based on a $10(15) \%$ maximal IV size is $16.38(8.96)$

$* * *, * *$, *Statistical significance at the 1,5 , and $10 \%$ levels respectively

\subsubsection{Export demand shocks and firm expansion}

If the transmission mechanism is due to liquidity constraints, then we should observe that the firm expands due to a positive export demand shock. In fact, Table 7 column (1) shows that a $10 \%$ increase in exports raises the number of employees of a firm by $1.7 \%$. Another way the firm can take advantage of larger exports is to increase its productivity. This can be done by hiring workers with higher productivity, or by investing in more efficient production technologies as in Lileeva and Trefler (2010) and Bustos (2011). Column (2) of Table 7 indicates that firms do pay higher wages when faced with a positive export demand shock. The result in column (1) rules out that this rise in average wages is due to firms firing employees. It must be that firms hire high-skilled workers so that both employment and wages per employee increase. Column (3) reveals that firms also increase their investments when faced with a boost in exports. In addition, the previous result that larger firms benefit less from export 
Table 7 Impact of exports on firm expansion

\begin{tabular}{|c|c|c|c|}
\hline Dep. variable & $\begin{array}{l}\text { In employment } \\
\text { it } \\
\text { (1) }\end{array}$ & $\begin{array}{l}\text { ln wage per } \\
\text { employee }_{i t} \\
\text { (2) }\end{array}$ & $\begin{array}{l}\text { In investment }{ }_{\mathrm{it}} \\
\text { (3) }\end{array}$ \\
\hline $\ln$ exports $_{i t}$ & $\begin{array}{l}0.168 * * \\
(0.066)\end{array}$ & $\begin{array}{l}0.137 * \\
(0.083)\end{array}$ & $\begin{array}{l}0.711 * * * \\
(0.267)\end{array}$ \\
\hline $\ln D D_{i t}$ & $\begin{array}{l}0.009 \\
(0.010)\end{array}$ & $\begin{array}{l}0.008 \\
(0.007)\end{array}$ & $\begin{array}{l}0.088 \\
(0.065)\end{array}$ \\
\hline $\ln$ imports $_{i t}$ & $\begin{array}{l}0.030 \text { *** } \\
(0.010)\end{array}$ & $\begin{array}{l}-0.014 \\
(0.012)\end{array}$ & $\begin{array}{l}0.093 * * \\
(0.042)\end{array}$ \\
\hline \multicolumn{4}{|l|}{ First-stage } \\
\hline $\ln F D_{i t}$ & $\begin{array}{l}0.080 \text { *** } \\
(0.015)\end{array}$ & $\begin{array}{l}0.080 * * * \\
(0.015)\end{array}$ & $\begin{array}{l}0.082 * * * \\
(0.016)\end{array}$ \\
\hline $\ln D D_{i t}$ & $\begin{array}{l}-0.009 \\
(0.029)\end{array}$ & $\begin{array}{l}-0.009 \\
(0.029)\end{array}$ & $\begin{array}{l}-0.006 \\
(0.032)\end{array}$ \\
\hline $\operatorname{ln~imports~}_{i t}$ & $\begin{array}{l}0.138 * * * \\
(0.007)\end{array}$ & $\begin{array}{l}0.138 * * * \\
(0.007)\end{array}$ & $\begin{array}{l}0.138 * * * \\
(0.009)\end{array}$ \\
\hline Observations & 65,496 & 65,496 & 56,934 \\
\hline$R^{2}$ & 0.93 & 0.85 & 0.59 \\
\hline KP-stat. & 27.03 & 27.03 & 26.74 \\
\hline
\end{tabular}

Standard errors clustered by sectors (2-digit NACE) are in parentheses. All regressions are estimated with 2SLS and include firm and sector-year fixed effects. The critical value of the Kleibergen-Paap (KP) statistic based on a $10 \%$ maximal IV size is 16.38

$* * *, * *$, *Statistical significance at the 1,5 , and $10 \%$ levels respectively

shocks can be explained by the fact that they are probably close to their optimal size. ${ }^{27}$ Overall, these results give support to the liquidity constraints hypothesis.

\subsection{Quantification exercise}

In this section, I quantify the results to get a sense of the magnitude of the effect of export demand shocks on Turkey's domestic sales. I follow the methodology proposed by di Giovanni et al. (2018) and later adapted to an international trade context by Héricourt and Nedoncelle (2018). Instead of focusing on variation of changes as done in those papers, I assess the influence of exogenous export demand shocks in driving aggregate changes in domestic sales to be more in line with the contribution of this paper. First, for each firm-year, I calculate changes in predicted domestic sales using the firm-level results with quartile size bins presented in Table 4 column (3). Then, I compute aggregate yearly predicted changes as follows:

\footnotetext{
27 In fact, running the regressions in Table 7 with firm size interactions shows that smaller firms expand more in terms of employment when faced with positive export demand shocks.
} 


$$
\Delta \hat{X}_{t}=\sum_{i} \omega_{i t-1} \times \Delta \hat{X}_{i t},
$$

where $\omega_{i t-1}$ are lagged firm-specific shares in total domestic sales, and $\hat{X}_{i t}$ is calculated by multiplying the observed exogenous export demand shock with its estimated first-stage coefficient (0.083), which is then multiplied by the estimated quartile coefficients from the second stage $(0.389,0.276,0.287$, and 0.176 for quartiles $1-4$ respectively, all statistically significant at least at the $5 \%$ level) ${ }^{28}$ It is important to take the difference in these coefficients into account since large firms, which drive aggregate results, react less to exogenous changes in exports when compared to the adjustments of small firms.

Table 8 column (1) shows the yearly predicted changes in domestic sales due to firm-specific export demand shocks. The figures are $<1 \%$ for all years, but to gauge the economic significance of these predicted changes, I divide these figures by the observed aggregate changes in domestic sales presented in column (2). This exercise reveals that the predicted changes in domestic sales due to export demand shocks can explain $1.36 \%$ of the observed changes on average, as shown in column (3). ${ }^{29}$ This figure is especially large for the Great Recession period in 2009, where the predicted change in domestic sales explains almost 5\% of the 11\% slump in Turkish domestic sales. This is intuitive since this period experienced a collapse in global demand combined with tight credit conditions.

I now turn to the more disaggregate quantification at the HS2 sector level to uncover heterogeneities in the effect of export demand shocks. For this exercise, I use the estimation results from the firm-product level regressions, presented in Table 5 column (2), to quantify the effect on produced domestic sales. Here, the aggregation is as follows:

$$
\Delta \hat{X}_{H S 2 t}=\sum_{i h} \omega_{i h t-1} \times \Delta \hat{X}_{i h t},
$$

where $\omega_{i h t-1}$ are lagged firm-product (HS6+) shares in domestic sales at the HS2 level (for $h \in H S 2$ ), and $\hat{X}_{i h t}$ is calculated by multiplying the observed exogenous export demand shock with its first-stage coefficient (0.157), which is then multiplied by the estimated second-stage coefficient $(0.469) .{ }^{30}$

Table 9 shows the results for Turkey's 10 largest manufacturing HS2 export sectors, based on these sectors' contribution to Turkey's total exports in 2006-2014 (as shown in column (4)). Column (1) shows that, similar to the results in Table 8, the predicted change due to export demand shocks is always $<1 \%$. However, as shown in column (2), the change in observed domestic sales for these top 10 sectors was at most $12.5 \%$ on average. In fact, Turkey's largest exporting sector, Vehicles and parts and accessories thereof (HS87; includes automobiles), which made up almost

\footnotetext{
28 The first-stage results show that exports react similarly to demand shocks regardless of quartile.

29 Averages are geometric means.

30 Note that, unlike in the aggregate quantification exercise, I do not use quartile coefficients here as the firm size interactions are not statistically significant when included in firm-product level estimations. These results are available on request.
} 
Table 8 Quantification exercise (by year)

\begin{tabular}{lrrr}
\hline Year & \multicolumn{1}{l}{$\Delta \hat{X}_{t}$} & \multicolumn{1}{c}{$\Delta X_{t}$} & $\begin{array}{l}\text { Explained } \\
\text { share (\%) } \\
\end{array}$ \\
\multicolumn{1}{l}{$(1)$} & \multicolumn{1}{c}{$(2)$} & \multicolumn{1}{c}{$(3)$} \\
\hline 2006 & 0.0018 & 0.2836 & 0.65 \\
2007 & 0.0025 & 0.0825 & 3.07 \\
2008 & 0.0025 & 0.1754 & 1.41 \\
2009 & -0.0051 & -0.1101 & 4.63 \\
2010 & 0.0027 & 0.1744 & 1.57 \\
2011 & 0.0023 & 0.2766 & 0.84 \\
2012 & -0.0003 & 0.0607 & -0.50 \\
2013 & 0.0004 & -0.0934 & -0.38 \\
2014 & 0.0012 & 0.1144 & 1.02 \\
Average & 0.0009 & 0.0988 & 1.36 \\
\hline
\end{tabular}

Explained share is calculated as $\Delta \hat{X}_{t} / \Delta X_{t}$. Averages are geometric means

a fifth of the country's exports in 2006-2014, experienced only about a $1 \%$ rise in produced domestic sales on average, of which about $7.3 \%$ can be explained by export demand shocks. This share reaches 13\% for two other large exporting sectors: Machinery and mechanical appliances, and parts thereof (HS84) and Other made up textile articles (HS63). These quantification results, both at the yearly and the HS2 levels, highlight the contribution of cross-border business cycle spillovers to domestic economic conditions.

\section{Conclusion}

This paper showed that export demand shocks positively influence firms' domestic sales in a large open developing country, Turkey, and that this result can be explained by (i) product-specific scale effects and (ii) the easing of liquidity constraints at the firm level. By instrumenting firms' exports with destination-product specific demand levels, I found that an exogenous 10\% rise in exports increases a firm's domestic sales by $2.6 \%$ on average. Results showed that this effect exists even for large firms, albeit with a smaller magnitude.

By analyzing the relationship at the firm-product level and shutting down liquidity constraints via firm-year fixed effects, I found that the complementary relationship between sales at home and abroad can largely be explained by same-product efficiency gains through scale effects, with coefficients that are almost twice as large as the ones found at the firm level. Still, by separating exports into produced and non-produced (or CAT) exports, I found that CAT exports also have an effect on domestic sales, hinting to the importance of non-production related firm-level spillovers such as liquidity constraints. Additional results on employment, wages, and investment suggest that temporary export demand shocks can influence firm-level expansion. 
Table 9 Quantification exercise (by HS2)

\begin{tabular}{|c|c|c|c|c|c|}
\hline \multirow[t]{2}{*}{ HS2 } & \multirow[t]{2}{*}{ Sector } & \multirow{2}{*}{$\begin{array}{l}\text { Avg. } \Delta \hat{X}_{H S 2} \\
\text { (1) }\end{array}$} & \multirow{2}{*}{$\begin{array}{l}\text { Avg. } \Delta X_{H S 2} \\
\text { (2) }\end{array}$} & \multirow{2}{*}{$\begin{array}{l}\text { Avg. } \\
\text { explained } \\
\text { share (\%) } \\
(3)\end{array}$} & \multirow{2}{*}{$\begin{array}{l}\text { Avg. share } \\
\text { of exports } \\
(\%) \\
(4)\end{array}$} \\
\hline & & & & & \\
\hline 29 & Organic chemicals & 0.0045 & 0.0864 & 7.82 & 1.21 \\
\hline 39 & Plastics and articles thereof & 0.0038 & 0.1247 & 0.99 & 3.98 \\
\hline 40 & Rubber and articles thereof & 0.0039 & 0.0606 & 3.99 & 3.52 \\
\hline 61 & Articles of apparel (knitted or crocheted) & 0.0020 & 0.1043 & 2.85 & 2.23 \\
\hline 63 & Other made up textile articles & 0.0032 & 0.0449 & 12.91 & 2.08 \\
\hline 72 & Iron and steel & 0.0020 & 0.0978 & 3.50 & 8.65 \\
\hline 73 & Articles of iron or steel & 0.0010 & 0.0903 & 3.32 & 2.56 \\
\hline 84 & $\begin{array}{l}\text { Machinery and mechanical appliances, } \\
\text { and parts thereof }\end{array}$ & 0.0021 & 0.0908 & 13.24 & 8.56 \\
\hline 85 & $\begin{array}{l}\text { Electrical machinery and equipment and } \\
\text { parts thereof }\end{array}$ & 0.0040 & 0.0902 & 9.64 & 5.81 \\
\hline 87 & Vehicles and parts and accessories thereof & 0.0017 & 0.0119 & 7.33 & 19.23 \\
\hline
\end{tabular}

Explained share is calculated as $\Delta \hat{X}_{H S 2 t} / \Delta X_{H S 2 t}$. For columns (1)-(3), averages are geometric means for each HS2 over 2006-2014. Column (4) shows the sector's average share of exports in 2006-2014

This paper contributes to the literature by identifying the channels between firms' sales in different markets. Findings in this paper emphasize the scale effects that are generated by exogenous increases in demand, and also indicate that the average firm might be liquidity constrained in Turkey during the 2005-2014 period. The quantification exercise indicated that about $1.4 \%$ of yearly changes in aggregate domestic sales can be explained by export demand shocks. This figure was found to be larger for certain periods, such as the Great Recession in 2009, when global demand collapsed. Policy implications for this paper hint to supporting exposed small-andmedium enterprises (SMEs), such as through subsidized credit, during "bad times" abroad, especially in important trading partner destinations. Another implication of my results is the importance of export-market diversification in order to suppress the potential adverse affects of recessions abroad. Future research should delve deeper and examine spillover effects between different export markets to better understand firms' profit maximization strategies when marginal costs are not constant.

Acknowledgements I am grateful to two anonymous referees, Richard Baldwin, Nicolas Berman, Maarten Bosker, Chad Bown, Julian Emami Namini, Laura Hering, Beata Javorcik, Sacha Kapoor, Vladimir Karamychev, Vincent Rebeyrol, Bauke Visser, and Yuan Zi for helpful comments, as well as seminar participants at the Erasmus School of Economics, the European University Institute, and the Graduate Institute of Geneva for useful feedback. I especially thank Gökalp Öz, Sevilay Özen, and Ayşe Öztürk at the Istanbul branch of the Turkish Statistical Institute (TÜIK) for providing me with the data and patiently answering my queries. All the analyses for this paper have been conducted at TÜIK under a confidentiality agreement. The results and opinions shown here are the responsibility of the author and do not necessarily reflect the views of any agency of the Turkish government. 
Open Access This article is distributed under the terms of the Creative Commons Attribution 4.0 International License (http://creativecommons.org/licenses/by/4.0/), which permits unrestricted use, distribution, and reproduction in any medium, provided you give appropriate credit to the original author(s) and the source, provide a link to the Creative Commons license, and indicate if changes were made.

\section{Appendix 1: Data cleaning}

There are 545,651 unique firms from all sectors in the Industry and Services Statistics database in 2005-2014. Since this paper is interested in the manufacturing sector, I merge this data with Industry Production Statistics using unique firm tax IDs to get 53,191 unique manufacturing firms. Then, I use the subset of manufacturing firms that have exported at least once in 2005-2014 (by merging with the Foreign Trade Statistics database using unique firm tax IDs); this gives me 26,738 firms. Further restricting the sample to firms with at least 20 employees results in 25,230 firms. In addition, in order to exclude unreliable data, I drop observations where exports are larger than total sales, or where production sales (the sum of firm-product level sales) are larger than total sales, to get 24,451 firms. Finally, I keep firms that have produced and exported at least one manufactured good in 2005-2014 to exclude firms that export only non-manufactured products (i.e. agriculture and raw materials). This results in 21,926 unique firms which make up about two-thirds of manufacturing sales and half of all manufacturing exports and imports.

\section{Appendix 2: The tariff instrument}

See Tables 10, 11, 12, 13.

At the firm level, the tariff instrument is constructed as:

$$
F_{T A R_{i t}}=\sum_{c h} \omega_{i c h}(\text { tariffs })_{c h t},
$$

where $\omega_{i c h}$ is the average weight of a destination-product in a firm's total exports in 2005-2014, and MFN tariffs are from UN Comtrade (WITS). I also include an analogous control for Turkey's MFN tariffs:

$$
D T A R_{i t}=\sum_{h} \eta_{i h}(\operatorname{tariffs})_{T U R, h t},
$$

where $\eta_{i h}$ is the average weight of a product in a firm's total exports in 2005-2014.

At the firm-product level, the instrument is constructed as:

$$
F T A R_{i h t}=\sum_{c} \omega_{i c h}(\text { tariffs })_{c h t},
$$

where $\omega_{i c h}$ is the average weight of a destination in a firm's exports of product $h$ in 2005-2014. The control variable $D T A R_{h t}$ at the firm-product level is simply Turkey's 
MFN tariffs on product $h$ at year $t$. In the regressions, I add 1 to $F T A R_{i h t}$ and DTAR before taking logs to keep observations with zero tariffs.

Table 10 OLS results

\begin{tabular}{|c|c|c|c|c|c|}
\hline \multirow{2}{*}{$\begin{array}{l}\text { Dep. vari- } \\
\text { able }\end{array}$} & \multicolumn{2}{|c|}{ ln total dom. sales ${ }_{i t}$} & \multicolumn{2}{|c|}{ ln prod. dom. sales ${ }_{i t}$} & \multirow{2}{*}{$\begin{array}{l}\text { In prod. dom. sales } \\
\text { (5) } \\
\text { (5) }\end{array}$} \\
\hline & (1) & (2) & (3) & (4) & \\
\hline $\ln _{\text {exports }}{ }_{i t}$ & $\begin{array}{l}-0.027 \\
(0.017)\end{array}$ & & $\begin{array}{l}0.019 * * * \\
(0.006)\end{array}$ & & \\
\hline $\ln _{\text {exports }}{ }_{i h t}$ & & & & & $\begin{array}{l}0.046^{* * * *} \\
(0.010)\end{array}$ \\
\hline ln prod. expo & orts $_{i t}$ & $\begin{array}{l}-0.021 \\
(0.016)\end{array}$ & & $\begin{array}{l}-0.027^{* * *} \\
(0.010)\end{array}$ & \\
\hline $\ln$ CAT expor & $\mathrm{rts}_{i t}$ & $\begin{array}{l}-0.008 \\
(0.014)\end{array}$ & & $\begin{array}{l}0.049 * * * \\
(0.003)\end{array}$ & \\
\hline $\ln D D_{i t}$ & $\begin{array}{l}0.032 \\
(0.029)\end{array}$ & $\begin{array}{l}0.062 \\
(0.041)\end{array}$ & $\begin{array}{l}0.016 \\
(0.029)\end{array}$ & $\begin{array}{l}0.040 \\
(0.044)\end{array}$ & \\
\hline $\ln D D_{i h t}$ & & & & & $\begin{array}{l}0.102 * * * \\
(0.022)\end{array}$ \\
\hline $\ln$ imports $_{i t}$ & $\begin{array}{l}0.079 * * * \\
(0.006)\end{array}$ & $\begin{array}{l}0.077 * * * \\
(0.008)\end{array}$ & $\begin{array}{l}0.082 * * * \\
(0.005)\end{array}$ & $\begin{array}{l}0.079 * * * \\
(0.007)\end{array}$ & \\
\hline $\begin{array}{l}\text { Fixed } \\
\text { effects }\end{array}$ & $\begin{array}{l}\text { Firm and } \\
\text { sector-year }\end{array}$ & $\begin{array}{l}\text { Firm and } \\
\text { sector-year }\end{array}$ & $\begin{array}{l}\text { Firm and } \\
\text { sector-year }\end{array}$ & $\begin{array}{l}\text { Firm and } \\
\text { sector-year }\end{array}$ & $\begin{array}{l}\text { Firm-product and } \\
\text { HS2-year and } \\
\text { Firm-year }\end{array}$ \\
\hline $\begin{array}{l}\text { Observa- } \\
\text { tions }\end{array}$ & 66,684 & 40,407 & 66,596 & 40,340 & 87,533 \\
\hline$R^{2}$ & 0.94 & 0.95 & 0.95 & 0.96 & 0.97 \\
\hline
\end{tabular}

Standard errors clustered by sectors (2-digit NACE) are in parentheses (except for column (5), where standard errors are clustered at the firm level). Products are at the HS6+ level

***,**, *Statistical significance at the 1,5 , and $10 \%$ levels respectively 
Table 11 Sensitivity analyses at the firm level

Initial weights Alternative $D D_{i t}$ Multiple markets Small importers +Tariff IV
(1) (2) (3)

(4)

(5)

(a) Dep. variable ln total domestic sales ${ }_{i t}$

\begin{tabular}{|c|c|c|c|c|c|}
\hline $\ln$ exports $_{i t}$ & $\begin{array}{l}0.304 * * * \\
(0.089)\end{array}$ & $\begin{array}{l}0.270 * * * \\
(0.084)\end{array}$ & $\begin{array}{l}0.350 * * \\
(0.151)\end{array}$ & $\begin{array}{l}0.134 * \\
(0.081)\end{array}$ & $\begin{array}{l}0.253 * * * \\
(0.068)\end{array}$ \\
\hline $\ln D D_{i t}$ & $\begin{array}{l}0.039 \\
(0.033)\end{array}$ & $\begin{array}{l}0.015 * * \\
(0.006)\end{array}$ & $\begin{array}{l}0.056^{*} \\
(0.033)\end{array}$ & $\begin{array}{l}0.025 \\
(0.027)\end{array}$ & $\begin{array}{l}0.034 \\
(0.032)\end{array}$ \\
\hline ln imports ${ }_{i t}$ & $\begin{array}{l}0.034 * * * \\
(0.012)\end{array}$ & $\begin{array}{l}0.038 * * * \\
(0.013)\end{array}$ & $\begin{array}{l}0.029 \\
(0.020)\end{array}$ & & $\begin{array}{l}0.041 * * * \\
(0.012)\end{array}$ \\
\hline $\ln D T A R_{i t}$ & & & & & $\begin{array}{l}0.041 \\
(0.037)\end{array}$ \\
\hline Observations & 65,496 & 65,284 & 54,978 & 41,781 & 65,496 \\
\hline$R^{2}$ & 0.89 & 0.90 & 0.91 & 0.91 & 0.91 \\
\hline KP-stat. & 19.33 & 28.26 & 13.01 & 5.48 & 14.14 \\
\hline Hansen- $p$ & - & - & - & - & 0.90 \\
\hline \multicolumn{6}{|c|}{ (b) Dep. variable: In produced domestic sales ${ }_{i t}$} \\
\hline $\ln _{\text {exports }}{ }_{i t}$ & $\begin{array}{l}0.259 * * * \\
(0.090)\end{array}$ & $\begin{array}{l}0.237 * * \\
(0.097)\end{array}$ & $\begin{array}{l}0.340 \\
(0.209)\end{array}$ & $\begin{array}{l}0.180 * * \\
(0.078)\end{array}$ & $\begin{array}{l}0.240 * * * \\
(0.088)\end{array}$ \\
\hline $\ln D D_{i t}$ & $\begin{array}{l}0.016 \\
(0.032)\end{array}$ & $\begin{array}{l}0.008 \\
(0.006)\end{array}$ & $\begin{array}{l}0.036 \\
(0.031)\end{array}$ & $\begin{array}{l}0.003 \\
(0.026)\end{array}$ & $\begin{array}{l}0.018 \\
(0.030)\end{array}$ \\
\hline $\ln$ imports $_{i t}$ & $\begin{array}{l}0.049 * * * \\
(0.012)\end{array}$ & $\begin{array}{l}0.053 * * * \\
(0.014)\end{array}$ & $\begin{array}{l}0.041 \\
(0.027)\end{array}$ & & $\begin{array}{l}0.052 * * * \\
(0.013)\end{array}$ \\
\hline $\ln D T A R_{i t}$ & & & & & $\begin{array}{l}0.006 \\
(0.024)\end{array}$ \\
\hline Observations & 65,409 & 65,197 & 54,900 & 41,700 & 65,409 \\
\hline$R^{2}$ & 0.92 & 0.92 & 0.92 & 0.91 & 0.92 \\
\hline KP-stat. & 19.96 & 29.26 & 12.90 & 5.51 & 14.57 \\
\hline Hansen- $p$ & - & - & - & - & 0.60 \\
\hline
\end{tabular}

Standard errors clustered by sectors (2-digit NACE) are in parentheses. All regressions are estimated with 2SLS and include firm and sector-year fixed effects. The critical value of the Kleibergen-Paap (KP) statistic based on a 10 (15)\% maximal IV size is 16.38 (8.96) for columns (1)-(4), and 19.93 (11.59) for column (5)

$* * *, * *, *$ Statistical significance at the 1,5 , and $10 \%$ levels respectively. See Table 12 for the corresponding first-stage results 
Table 12 First-stage results for Table 11

Instrumented var.: Initial weights Alternative $D D_{i t}$ Multiple markets Small importers +Tariff IV
ln exports it $_{\text {. }}$

(3)

(4)

(5)

(a) Dep. variable: In total domestic sales ${ }_{i t}$

\begin{tabular}{|c|c|c|c|c|c|}
\hline $\ln F D_{i t}$ & $\begin{array}{l}0.075 * * * \\
(0.017)\end{array}$ & $\begin{array}{l}0.080 * * * \\
(0.015)\end{array}$ & $\begin{array}{l}0.057 * * * \\
(0.016)\end{array}$ & $\begin{array}{l}0.093 * * \\
(0.040)\end{array}$ & $\begin{array}{l}0.081 * * * \\
(0.015)\end{array}$ \\
\hline \multirow[t]{2}{*}{$\ln D D_{i t}$} & -0.020 & -0.003 & -0.016 & -0.018 & -0.009 \\
\hline & $(0.030)$ & $(0.013)$ & $(0.027)$ & $(0.033)$ & $(0.029)$ \\
\hline \multirow[t]{2}{*}{$\ln$ imports $_{i t}$} & $0.138 * * *$ & $0.138 * * *$ & $0.131 * * *$ & & $0.138 * * *$ \\
\hline & $(0.007)$ & $(0.007)$ & $(0.008)$ & & $(0.007)$ \\
\hline \multirow[t]{2}{*}{$\ln F T A R_{i t}$} & & & & & -0.017 \\
\hline & & & & & $(0.027)$ \\
\hline \multirow[t]{2}{*}{$\ln D T A R_{i t}$} & & & & & -0.026 \\
\hline & & & & & $(0.074)$ \\
\hline Observations & 65,496 & 65,284 & 54,978 & 41,781 & 65,496 \\
\hline$R^{2}$ & 0.89 & 0.90 & 0.91 & 0.91 & 0.91 \\
\hline KP-stat. & 19.33 & 28.26 & 13.01 & 5.48 & 14.14 \\
\hline Hansen- $p$ & - & - & - & - & 0.90 \\
\hline \multicolumn{6}{|c|}{ (b) Dep. variable: $\ln$ produced domestic sales ${ }_{i t}$} \\
\hline \multirow[t]{2}{*}{$\ln F D_{i t}$} & $0.076^{* * *}$ & $0.081 * * *$ & $0.057 * * *$ & $0.094 * *$ & $0.082 * * *$ \\
\hline & $(0.017)$ & $(0.015)$ & $(0.016)$ & $(0.040)$ & $(0.015)$ \\
\hline \multirow[t]{2}{*}{$\ln D D_{i t}$} & -0.019 & -0.003 & -0.015 & -0.016 & -0.009 \\
\hline & $(0.030)$ & $(0.014)$ & $(0.027)$ & $(0.033)$ & $(0.029)$ \\
\hline \multirow[t]{2}{*}{$\ln _{\text {imports }}{ }_{i t}$} & $0.138 * * *$ & $0.137 * * *$ & $0.130 * * *$ & & $0.137 * * *$ \\
\hline & $(0.007)$ & $(0.007)$ & $(0.008)$ & & $(0.007)$ \\
\hline \multirow[t]{2}{*}{$\ln F T A R_{i t}$} & & & & & -0.017 \\
\hline & & & & & $(0.027)$ \\
\hline \multirow[t]{2}{*}{$\ln D T A R_{i t}$} & & & & & -0.024 \\
\hline & & & & & $(0.075)$ \\
\hline Observations & 65,409 & 65,197 & 54,900 & 41,700 & 65,409 \\
\hline$R^{2}$ & 0.92 & 0.92 & 0.92 & 0.91 & 0.92 \\
\hline KP-stat. & 19.96 & 29.26 & 12.90 & 5.51 & 14.57 \\
\hline Hansen- $p$ & - & - & - & - & 0.60 \\
\hline
\end{tabular}

Standard errors clustered by sectors (2-digit NACE) are in parentheses. All regressions are estimated with 2SLS and include firm and sector-year fixed effects. The critical value of the Kleibergen-Paap (KP) statistic based on a 10 (15)\% maximal IV size is 16.38 (8.96) for columns (1)-(4), and 19.93 (11.59) for column (5).

$* * *, * *$, *Statistical significance at the 1,5 , and $10 \%$ levels respectively 
Table 13 Robustness check for market power

\begin{tabular}{|c|c|c|c|c|c|c|}
\hline \multirow{2}{*}{$\begin{array}{l}\text { Dep. vari- } \\
\text { able }\end{array}$} & \multicolumn{2}{|c|}{ In total domestic sales ${ }_{i t}$} & \multicolumn{2}{|c|}{ In prod. domestic sales ${ }_{i t}$} & \multicolumn{2}{|c|}{ In prod. domestic sales ${ }_{i h t}$} \\
\hline & $\begin{array}{l}50 \% \\
(1)\end{array}$ & $\begin{array}{l}10 \% \\
(2)\end{array}$ & $\begin{array}{l}50 \% \\
(3)\end{array}$ & $\begin{array}{l}10 \% \\
(4)\end{array}$ & $\begin{array}{l}50 \% \\
(5)\end{array}$ & $\begin{array}{l}10 \% \\
(6)\end{array}$ \\
\hline $\ln _{\text {exports }}{ }_{i t}$ & $\begin{array}{l}0.190 * * * \\
(0.060)\end{array}$ & $\begin{array}{l}0.201 * * * \\
(0.070)\end{array}$ & $\begin{array}{l}0.171 * \\
(0.086)\end{array}$ & $\begin{array}{l}0.260 * * \\
(0.111)\end{array}$ & & \\
\hline ln exports iht $_{1}$ & & & & & $\begin{array}{l}0.463 * * * \\
(0.156)\end{array}$ & $\begin{array}{l}0.482 * * * \\
(0.185)\end{array}$ \\
\hline $\ln D D_{i t}$ & $\begin{array}{l}0.035 \\
(0.031)\end{array}$ & $\begin{array}{l}0.037 \\
(0.032)\end{array}$ & $\begin{array}{l}0.019 \\
(0.029)\end{array}$ & $\begin{array}{l}0.021 \\
(0.030)\end{array}$ & & \\
\hline $\ln D D_{i h t}$ & & & & & $\begin{array}{l}0.081 * * * \\
(0.026)\end{array}$ & $\begin{array}{l}0.081 * * * \\
(0.027)\end{array}$ \\
\hline $\ln _{\text {imports }}{ }_{i t}$ & $\begin{array}{l}0.050 * * * \\
(0.010)\end{array}$ & $\begin{array}{l}0.048 * * * \\
(0.013)\end{array}$ & $\begin{array}{l}0.062 * * * \\
(0.012)\end{array}$ & $\begin{array}{l}0.050 * * * \\
(0.016)\end{array}$ & & \\
\hline First-stage & & & & & & \\
\hline $\ln F D_{i t}$ & $\begin{array}{l}0.107 * * * \\
(0.020)\end{array}$ & $\begin{array}{l}0.095 * * * \\
(0.018)\end{array}$ & $\begin{array}{l}0.108 * * * \\
(0.019)\end{array}$ & $\begin{array}{l}0.096 * * * \\
(0.018)\end{array}$ & & \\
\hline $\ln F D_{i h t}$ & & & & & $\begin{array}{l}0.191 * * * \\
(0.040)\end{array}$ & $\begin{array}{l}0.168 * * * \\
(0.039)\end{array}$ \\
\hline $\ln D D_{i t}$ & $\begin{array}{l}-0.015 \\
(0.028)\end{array}$ & $\begin{array}{l}-0.017 \\
(0.030)\end{array}$ & $\begin{array}{l}-0.015 \\
(0.029)\end{array}$ & $\begin{array}{l}-0.016 \\
(0.030)\end{array}$ & & \\
\hline $\ln D D_{i h t}$ & & & & & $\begin{array}{l}0.027 \\
(0.032)\end{array}$ & $\begin{array}{l}0.027 \\
(0.033)\end{array}$ \\
\hline $\ln _{\text {imports }}{ }_{i t}$ & $\begin{array}{l}0.137 * * * \\
(0.007)\end{array}$ & $\begin{array}{l}0.139 * * * \\
(0.007)\end{array}$ & $\begin{array}{l}0.137 * * * \\
(0.007)\end{array}$ & $\begin{array}{l}0.138 * * * \\
(0.007)\end{array}$ & & \\
\hline
\end{tabular}

Fixed effects Firm and Firm and Firm and Firm and Firm-prod- Firm-product sector-year sector-year sector-year sector-year uct and and HS2-year HS2-year and firm-year and firm-

year

\begin{tabular}{lllllll}
\hline Observations & 65,330 & 64,515 & 65,243 & 64,428 & 83,463 & 77,692 \\
$R^{2}$ & 0.92 & 0.92 & 0.93 & 0.91 & 0.97 & 0.96 \\
KP-stat. & 29.78 & 28.50 & 30.89 & 29.07 & 22.66 & 18.20
\end{tabular}

Standard errors clustered by sectors (2-digit NACE) are in parentheses (except for columns (5)-(6), where the standard errors are clustered at the firm level). All regressions are estimated with 2SLS. The critical value of the Kleibergen-Paap (KP) statistic based on a $10 \%$ maximal IV size is 16.38

$* * *, * *, *$ Statistical significance at the 1,5 , and $10 \%$ levels respectively 


\section{References}

Abreha, K. G., Smeets, V., Warzynski, F., et al. (2013). Coping with the crisis: Recent evolution in Danish firms' international trade involvement, 2000-2010. (Economics Working Papers, pp. 20132015). Aarhus University.

Ahn, J., \& McQuoid, A. F. (2017). Capacity constrained exporters: Identifying increasing marginal cost. Economic Inquiry, 55(3), 1175-1191.

Almunia, M., Antràs, P., Lopez-Rodriguez, D., \& Morales, E. (2018). Venting out: Exports during a domestic slump. (Banco de Espana Working Paper 1844).

Arnarson, B. T. (2016). The superstar and the followers: Intra-firm product complementarity in international trade. (Working Papers, 2016(25)). Lund University, Department of Economics.

Atkin, D., Khandelwal, A. K., \& Osman, A. (2017). Exporting and firm performance: Evidence from a randomized experiment. The Quarterly Journal of Economics, 132(2), 551-615.

Beck, T., Demirgüç-Kunt, A., \& Maksimovic, V. (2005). Financial and legal constraints to growth: Does firm size matter? The Journal of Finance, 60(1), 137-177.

Berman, N., Berthou, A., \& Héricourt, J. (2015). Export dynamics and sales at home. Journal of International Economics, 96(2), 298-310.

Berman, N., Martin, P., \& Mayer, T. (2012). How do different exporters react to exchange rate changes? The Quarterly Journal of Economics, 127(1), 437-492.

Bernard, A. B., Blanchard, E. J., Van Beveren, I., \& Vandenbussche, H. Y. (2019). Carry-along trade. The Review of Economic Studies, 86(2), 526-563.

Bernard, A. B., Bøler, E. A., Massari, R., Reyes, J.-D., \& Taglioni, D. (2017). Exporter dynamics and partial-year effects. The American Economic Review, 107(10), 3211-3228.

Bugamelli, M., Gaiotti, E., \& Viviano, E. (2015). Domestic and foreign sales: Complements or substitutes? Economics Letters, 135(C), 46-51.

Bustos, P. (2011). Trade liberalization, exports, and technology upgrading: Evidence on the impact of MERCOSUR on Argentinian firms. The American Economic Review, 101(1), 304-340.

Cameron, A. C., Gelbach, J. B., \& Miller, D. L. (2011). Robust inference with multiway clustering. Journal of Business and Economic Statistics, 29(2), 238-249.

Chaney, T. (2008). Distorted gravity: The intensive and extensive margins of international trade. The American Economic Review, 98(4), 1707-1721.

Cooley, T. F., \& Quadrini, V. (2001). Financial markets and firm dynamics. The American Economic Review, 91(5), 1286-1310.

De Loecker, J. (2007). Do exports generate higher productivity? Evidence from Slovenia. Journal of International Economics, 73(1), 69-98.

De Loecker, J. (2011). Product differentiation, multiproduct firms, and estimating the impact of trade liberalization on productivity. Econometrica, 79(5), 1407-1451.

De Loecker, J. (2013). Detecting learning by exporting. American Economic Journal: Microeconomics, 5(3), 1-21.

di Giovanni, J., Levchenko, A. A., \& Mejean, I. (2018). The micro origins of international business-cycle comovement. The American Economic Review, 108(1), 82-108.

Di Nino, V. (2015). The phenomenal CAT: Firms clawing the goods of others. (The Occasional Papers). Bank of Italy.

Diewert, W. E., \& Fox, K. J. (2008). On the estimation of returns to scale, technical progress and monopolistic markups. Journal of Econometrics, 145(1-2), 174-193.

Ekholm, K., Moxnes, A., \& Ulltveit-Moe, K. H. (2012). Manufacturing restructuring and the role of real exchange rate shocks. Journal of International Economics, 86(1), 101-117.

Forbes, K. J. (2007). One cost of the Chilean capital controls: Increased financial constraints for smaller traded firms. Journal of International Economics, 71(2), 294-323.

Hummels, D., Jørgensen, R., Munch, J., \& Xiang, C. (2014). The wage effects of offshoring: Evidence from Danish matched worker-firm data. The American Economic Review, 104(6), 1597-1629.

Héricourt, J., \& Nedoncelle, C. (2018). Multi-destination firms and the impact of exchange-rate risk on trade. Journal of Comparative Economics, 46(4), 1178-1193.

Kohn, D., Leibovici, F., \& Szkup, M. (2016). Financial frictions and new exporter dynamics. International Economic Review, 57(2), 453-486.

Lileeva, A., \& Trefler, D. (2010). Improved access to foreign markets raises plant-level productivity... For some plants. The Quarterly Journal of Economics, 125(3), 1051-1099. 
Manova, K. (2013). Credit constraints, heterogeneous firms, and international trade. Review of Economic Studies, 80(2), 711-744.

Mayer, T., Melitz, M. J., \& Ottaviano, G. I. (2016). Product mix and firm productivity responses to trade competition. (NBER Working Paper No. 22433).

Melitz, M. J. (2003). The impact of trade on intra-industry reallocations and aggregate industry productivity. Econometrica, 71(6), 1695-1725.

Pierce, J. R., \& Schott, P. K. (2009). Concording US Harmonized System categories over time. (NBER Working Paper 15548).

Rajan, R., \& Zingales, L. (1998). Financial dependence and growth. The American Economic Review, $88(3), 559-586$.

Soderbery, A. (2014). Market size, structure, and access: Trade with capacity constraints. European Economic Review, 70(C), 276-298.

The World Bank (2013). Enterprise Surveys (http://www.enterprisesurveys.org).

Van Beveren, I., Bernard, A. B., \& Vandenbussche, H. (2012). Concording EU trade and production data over time. (NBER Working Paper No. 18604).

van den Berg, M., Boutorat, A., \& Alberda, A.-P. (2019). Dissecting carry-along trade: What's in the bundle? (CPB Discussion Paper February 2019).

Vannoorenberghe, G. (2012). Firm-level volatility and exports. Journal of International Economics, 86(1), 57-67.

Publisher's Note Springer Nature remains neutral with regard to jurisdictional claims in published maps and institutional affiliations. 